Prof. dr. Sead SELIMOVIĆ

Filozofski fakultet Univerziteta u Tuzli

E-mail: sead.selimovic@gmail.com

Stručni rad/Professional article

UDK/UDC: 94:316.454.3:355.4(497.5)"1991/1995"

Škiljan F. (049.3)

DOI: https://doi.org/10.52259/historijskipogledi.2021.4.5.313

\title{
Filip Škiljan, SJEĆANJA BOŠNJAKA NA SUDJELOVANJE U DOMOVINSKOM RATU U HRVATSKOJ, Vijeće bošnjačke nacionalne manjine Grada Zagreba, Zagreb 2020, 328 str.
}

Godine 2020, iz štampe je izašla knjiga Sjećanja Bošnjaka na sudjelovanje u Domovinskom ratu u Hrvatskoj, autora Filipa Škiljana. Izdavač knjige je Vijeće bošnjačke nacionalne manjine Grada Zagreba, a recenzenti su prof. dr. Sead Selimović i prof. dr. Sead Berberović. Knjigu je grafički oblikovao i štampao Grafocentar d.o.o. Lekturu i korekturu uradila je Lada Ledić, profesor.

Knjiga

Sjećanja Bošnjaka na sudjelovanje $u$ Domovinskom ratu u Hrvatskoj, sastoji se iz slijedećih dijelova:

- Uvod

- Povijest Bošnjaka u Hrvatskoj u novije doba - ukratko (prva doseljavanja muslimana u hrvatske krajeve nakon 1878. godine, Kraljevina SHS/Jugoslavija, Vrijeme NDH, Vrijeme nakon 1945); Početak

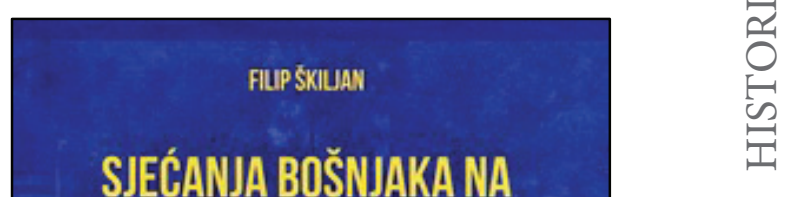

Domovinskog rata u Hrvatskoj i uloga Muslimana/Bošnjaka u Domovinskom ratu (Organiziranje Muslimana u Hrvatskoj nakon početka Domovinskog rata, Pomoć Hrvatske Bosni i Hercegovini, Sudjelovanje Bošnjaka u obrani Republike Hrvatske, Terenska istraživanja o sudjelovanju Muslimana/Bošnjaka u Domovinskom ratu u 
Hrvatskoj, Odraz sukoba Bošnjaka i Hrvata u srednjoj Bosni i Hercegovini na položaj Bošnjaka u Hrvatskoj.

- Sjećanje Bošnjaka (Muslimana) na Domovinski rat u Hrvatskoj (Zagreb i okolica; Varaždin; Dalmacija; Slavonija; Karlovac i Sisak; Istra i Rijeka.)

- Pogovor

- Izvori i literatura

Autor u knjizi piše o doprinosu Bošnjaka odbrani Republike Hrvatske u Domovinskom ratu od 1992. do 1995. godine. On ističe da su nacionalne manjine u Hrvatskoj dale "izniman doprinos u Domovinskom ratu".

Mnogobrojni hrvatski branitelji nisu pripadali većinskom hrvatskom narodu, već su bili pripadnici jedne od 22 priznate nacionalne manjine u Republici Hrvatskoj. Među tim manjinama svoje posebno mjesto zaslužuju Bošnjaci koji su svojim uključivanjem u Hrvatsku vojsku nadmašivali svoj udio u postotku u stanovništvu Republike Hrvatske. Naime, u Hrvatskoj nije bilo postrojbe u kojoj nije bilo Bošnjaka koji su branili svoju domovinu, ističe autor. Veliki broj Bošnjaka koji su služili u Hrvatskoj vojsci priključili su se "dragovoljno, braneći Hrvatsku već od prvih dana rata".

Autor piše da je u Dalmaciji bio osobit angažman bošnjačkih branitelja od samih početaka: od Dubrovnika gdje su Bošnjaci činili značajan postotak branitelja grada i gdje su se borili rame uz rame zajedno s građanima hrvatske nacionalnosti i onda kada se činilo da će grad pasti, preko Splita gdje su se Bošnjaci dragovoljno prijavljivali u Krizni štab i odakle su odlazili na brojna bojišta, do Šibenika i Zadra gdje su zauzimali značajne pozicije u obrani i držanju prvih linija. Iz Rijeke, Krka i Istre su riječki i istarski Bošnjaci u golemom postotku u odnosu na broj vojno sposobnih muškaraca odlazili na ličko bojište i ondje držali prve linije kod Otočca i Gospića, a kod Karlovca su brojni Bošnjaci branili Turanj, Mekušje i liniju obrane na rijeci Korani sprečavajući da srpske snage prodru u grad. Osobit značaj imali su Bošnjaci na području Siska koji su zajedno s Hrvatima branili grad s juga, jugoistoka i jugozapada (od Sunje, preko Komareva do Mošćenice). Posebno su se istaknuli Bošnjaci iz Zagreba koji su sudjelovali u svim zagrebačkim postrojbama i koji su se borili na svim hrvatskim bojišnicama. Vrlo važno mjesto u obrani Hrvatske imaju Bošnjaci Osijeka, Gunje i Slavonskog Broda koji su u velikom broju branili prostor uz Savu i uz Dravu prkoseći mnogobrojnijim neprijateljima s bosanske strane Save i s područja okupiranog dijela Hrvatske.

U ovoj knjizi autor je prikupio iskaze pojedinih Bošnjaka, odnosno osoba koje su bošnjačkog porijekla (a koji se nužno ne izjašnjavaju kao Bošnjaci!) kako bi ukazao na činjenicu koliko su Bošnjaci dali Hrvatskoj, na koji su način pomagali i sudjelovali u odbrani i koliko su svojim osobnim angažmanom bili uključeni u teške trenutke stvaranja neovisne Hrvatske.

U knjigu nisu uključeni samo bošnjački branitelji već i oni koji su svojim političkim, ekonomskim i drugim angažmanima pomagali odbranu 
Hrvatske. "Životni putevi intervjuiranih kazivača nakon rata su se razišli, ali su u vremenima agresije na Hrvatsku svi zajedno davali svoje srce za obranu gradova i naselja u kojima su živjeli, ali i za obranu krajeva koji su bili daleko od njihovih domova, a koji su bili napadnuti. Mnogi su Bošnjaci pristupili Hrvatskoj vojsci došavši iz različitih zapadnoevropskih zemalja, iz Bosne i Hercegovine i iz Sandžaka. Mnogi od njih nikada nisu evidentirani u popisima branitelja. Mnogi od Bošnjaka su živjeli u Hrvatskoj, ali su bili prijavljeni u Bosni i Hercegovini. I oni su se borili u redovima Hrvatske vojske, ali nikada nisu zabilježeni u popisima“, ističe autor.

U knjizi se događaji i procesi prate hronološkim redom, onako kako su se dešavali i kako su imali uticaja na ukupne prilike u Hrvatskoj od 1992. do 1995. godine. Autor piše ukratko o povijesti Bošnjaka u Hrvatskoj u novije doba (prva doseljavanja muslimana u hrvatske krajeve nakon 1878. godine, Kraljevina SHS/Jugoslavija, Vrijeme NDH, Vrijeme nakon 1945), zatim o početku Domovinskog rata u Hrvatskoj i ulozi Muslimana/Bošnjaka u Domovinskom ratu (Organiziranje Muslimana u Hrvatskoj nakon početka Domovinskog rata, Pomoć Hrvatske Bosni i Hercegovini, Sudjelovanje Bošnjaka u obrani Republike Hrvatske, Terenska istraživanja o sudjelovanju Muslimana/Bošnjaka u Domovinskom ratu u Hrvatskoj, Odrazu sukoba Bošnjaka i Hrvata u srednjoj Bosni i Hercegovini i odnos prema Bošnjacima u Hrvatskoj 1993-1994). Autor, dalje, piše o sjećanju Bošnjaka (Muslimana) na Domovinski rat u Hrvatskoj (Zagreb i okolica; Varaždin; Dalmacija; Slavonija; Karlovac i Sisak; Istra i Rijeka), donoseći činjenice koje su do sada bile nepoznate ili pak djelimično poznate stručnoj i znanstvenoj javnosti.

O doprinosu Bošnjaka i drugih nacionalnih manjina u Hrvatskoj nije dovoljno pisano u hrvatskoj historiografiji. Stoga je, kaže autor, i ova knjiga tek početak jednog ozbiljnijeg istraživanja o sudjelovanju Bošnjaka u Domovinskom ratu, tek jedan pokušaj sumiranja materijala koji je prikupljen, a nikako konačna studija koja bi dala cjelovitu sliku onoga što se događalo, odnosno kompletnog pregleda udjela Bošnjaka u Domovinskom ratu. Autor dalje ističe: "U svakom slučaju, bez obzira na činjenicu što ne možemo donijeti konačne i pouzdane podatke o broju Bošnjaka koji su sudjelovali $u$ Domovinskom ratu, svakako možemo reći da su Bošnjaci po broju svojih žrtava zadužili Hrvatsku i ugradili ono najvrednije u temelje hrvatske samostalnosti svoje živote“.

Važno mjesto u knjizi zauzimaju prilozi (str. 274-328). U njima autor donosi važne historijske izvore: akte, fotografije, plakate i faksimile novina, koje upotpunjuju tekst i doprinose njegovome boljem razumijevanju.

Ova knjiga se pojavljuje u vrijeme kada smo svjedoci sve učestalije pristrasnosti u historiji i drugim znanostima:

- kada se ne koriste pravila provjeravanja, metoda i logike;

- kada selektivnost nije u funkciji procesa spoznaje, tj. odgovaranja na istraživačko pitanje, nego potječe iz određenoga političkoga interesa; 
- $\quad$ kada se onemogućuje spoznajni postupak, jer se odustaje od revizije, promjene ili dopune unaprijed prihvaćenih gledišta iako ih izvori opovrgavaju;

- $\quad$ kada se ne uzimaju u obzir postojeći znanstveni rezultati;

- kada se sadržaj historijskoga iskaza „prilagođava” političkim ciljevima koji proturječje pravilima provjeravanja, argumentacije i logike;

- $\quad$ kada se historijsko znanje uptrebljava za politički pritisak sa svrhom da se onemogući znanstvena historija koja ne odgovara vladajućim ili preovladavajućim ideologijama. ${ }^{1}$

S obzirom na činjenicu da je autor profesionalni historičar (povjesničar), on nije upao u zamku da ideologizira ovo istraživačko pitanje. Ideologizirana historija je, na žalost, postala neminovna u svakodnevnoj političkoj diskusiji, u sukobu političkih stranaka, u medijima, u slavljenju godišnjica, a posebno u govorima političara. Argumenti iz historije upotrebljavaju se za diskreditaciju političkih protivnika ili onih koji ne misle u skladu s preovladavajućom ideologijom. Najčešće, to se čini historijskim primjerima, konstrukcijom analogija, tvrdnjama o kontinuitetu nekih pojava od njihovoga postanka do danas. $^{2}$

Autor je dobro postavio istraživačko pitanje, odabrao aktuelnu i važnu temu te uspješno odgovorio na istraživačko pitanje. Prilikom pisanja rada jasno je postavio cilj i zadatke istraživanja. Do rezultata istraživanja, koje je vrlo jasno prikazao, došao je tako što je koristio historijske izvore različite provenijencije. Izvršio je pravilnu selekciju izvora, izvršio kritiku i interpretaciju onako kako to nalaže metodologija historijskih istraživanja. Autor je u radu donio 190 fusnota i time omogućio provjerljivost što i jeste jedno od obilježja znanstvenog rada. Cijeli tekst rada je izuzetno jasan, kao što su jasni i rezultati istraživanja

Osim toga, autor je koristio metode važne za historijsko istraživanje (historijska metoda, metoda analize i sinteze, indukcije i dedukcije, statističku metodu, intervju), a razina korištenih metoda je vrlo visoka. Koristio je historijske izvore i literaturu različite provenijencije (domaću i stranu), a selekciju je vršio u cilju odgovora na istraživačko pitanje, čime je izbjegao zamku da bude pristrasan. Popis citiranih bibliografskih jedinica je potpun i konzistentan sa navođenjem u tekstu rukopisa, a zaključci vrlo jasni i uvjerljivi.

Rad je pisan standardnim hrvatskim jezikom, a tekst je jasno i logično struktuiran. Pravilno su oblikovana poglavlja i podnaslovi a korištena je relevantna historijska terminologija.

$\mathrm{Na}$ osnovu navedenih činjenica može se konstatovati da je knjiga Sjećanja Bošnjaka na sudjelovanje u Domovinskom ratu u Hrvatskoj, autora dr. sc. Filipa Škiljana, znanstveno djelo koje će, bez sumnje, predstavljati značajan doprinos hrvatskoj i regionalnoj historiografiji.

\footnotetext{
${ }^{1}$ Vidi: Mirjana Gross, Suvremena historiografija: korijeni, postignuća, traganja, Zagreb 1996.

${ }^{2}$ Isto.
} 
Knjiga je znanstveno-istraživačko djelo po svome predmetu istraživanja, sadržaju i metodološkom pristupu. Autor je rad prilagodio čitaocima svih nivoa obrazovanja, što mu, između ostaloga, i daje dodatnu vrijednost. Oni piše sine ira et studio, onako kako i treba da piše profesionalni historičar. Knjiga obiluje mnogim informacijama koje govore o doprinosu Bošnjaka odbrani Republike Hrvatske u Domovinskom ratu, te činjenicama koje proširuju spoznaju o ovome periodu hrvatske zbilje.

Zbog svega navedenog, knjigu preporučujem stručnoj i znanstvenoj javnosti, ali i široj čitalačkoj publici. 